\title{
A STUDY ON WATER QUALITY OF RAW WATER SOURCES OF PDAM (MUNIPICAL WATER COMPANY) BANDARMASIH
}

\author{
Ulfa Fitriati ${ }^{1}$, Novitasari ${ }^{2}$, and Ellysa Eriyanie ${ }^{3}$ \\ Civil Engineering Department, Lambung Mangkurat University. Jl. A. Yani Km. 35 Banjarbaru \\ South Kalimantan, Indonesia. Tel./Fax. +625114773868, \\ 1email: ulfa_fitriatist@yahoo.co.id, ${ }^{2}$ novitasari.st.mt@gmail.com
}

\begin{abstract}
High demand for clean water in Banjarmasin requires PDAM Bandarmasih to do some developments, but its efforts are hindered by the water quality of raw water to be processed. It is therefore necessary to conduct a study on the water quality of raw water sources of PDAM Bandarmasih, especially during dry season. Water quality testing was carried out by performing direct experiments in the field and in the laboratory with 7 criteria including water temperature, electrical conductivity, total dissolved solids, $\mathrm{pH}$, turbidity, salinity and dissolved oxygen that were compared with the criteria of water class B (water that can be used as the raw water for drinking water), on the basis of the Regulation of the Minister of Health of the Indonesia Republic No. 492/Menkes/PER/IV/2010. Based on the analyses of water quality in the field and in the laboratory from 4 intakes namely Sungai Tabuk, Pematang Panjang, Sungai Lulut and Sungai Bilu, and the comparison of the results with the test results of water quality of the samples from PDAM taken in dry season, indicated that the amount of salt content (salinity) in two intakes, Sungai Lulut and Sungai Bilu was so high that the production of clean water from both intakes was stopped temporarily during the dry season. The service for clean water was therefore provided only at the intakes of Sungai Tabuk and Pematang Panjang during dry season, resulting in some reduction in distribution to some areas in Banjarmasin.
\end{abstract}

Keywords: quality, intake, salinity, PDAM Bandarmasih

\section{INTRODUCTION}

Water sources play an important role in supporting the lives of individuals and communities, the social and economic development of a region, and the ecosystem of the environment. Various economic activities such as supplying raw water for household, agriculture, municipal need, industry, and energy always require the quantity and quality that should be in accordance with the demands and the reliable and sustainable services. The management of water sources encounters many complex issues in line with the increasing population accompanied by the rapid social and economic growth.

The population growth will increase the demand for water for various purposes and will also lead to the exploitation of carrying capacity of water sources. The water demand is increasing along with the population growth, the improvement of living standards, and the economic growth. The economic growth in a region has impacts on the population growth through the increasing fertility, the higher chance of survival and the mobility.

Banjarmasin city is the Regional Activity Center (RAG), as the city of the Central Governance (the capital of South Kalimantan Province) as well as a national gateway for the towns that are the centers of economic activities. It is also an important city in South Kalimantan region, which has a very strategic position geographically. Banjarmasin, therefore, deserves to be upgraded to become the National Events Centre in the future.

Banjarmasin is located at $3^{\circ} 15^{\prime}$ to $3^{\circ} 22^{\prime}$ south latitude and $114^{\circ} 32^{\prime}$ east longitude, the real altitude of land is at 0.16 $\mathrm{m}$ below sea level and almost all area of Banjarmasin will be flooded at high tide. The location of Banjarmasin is almost in the middle of Indonesia. It is on the east bank of Barito River and split by Martapura River tipped in Meratus Mountain. It is influenced by the tide of Java Ocean, and therefore contributes to the city's drainage and provides distinctive characteristics for people's lives, especially the use of the river as a water transport infrastructure, tourism, fishery and trade. 
The entire population of Banjarmasin use PDAM water as the source for clean water apart from the water from Martapura river. Because Banjarmasin is below sea level and is a swampy area, the citizens cannot use water from shallow ground wells. It results in high rates of water demand in Banjarmasin that requires a study on the water quality of raw water sources at PDAM Bandarmasih in Banjarmasin, especially during dry season. The purpose of this study is to assess the water quality of raw water sources at PDAM Bandarmasin during dry season.

\section{Definition of Clean Water and Drinking Water}

Clean water is one of the resources of water of good quality commonly used by humans for consumption or in performing their day to day activities including sanitation. Drinking water is water whose qualities meet the health requirements to be consumed.

\section{Requirements of Water Quality}

Water must meet some requirements so that the water is suitable for consumption and can meet the water demands of the community in the present and in the future. These requirements are:

The quantity requirements of fresh water mean that the water must meet the standards called water demand standards. The water demand standard is the water capacity normally required by humans to meet their needs of everyday life. The water demand standards are taken into account based on the observation of clean water usage in the daily life of consumers. The quantity of water should be maximized to meet the demand for clean water in the present and the future.

The terms for continuity of supplying clean water are closely related to the quantity of water available, the raw water in nature. The definition of continuity here is that the raw water for clean water can be taken continuously with discharge fluctuations relatively fixed, either during dry season or rainy season.

Clean Water Quality Requirements are the quality criteria of water sources in Indonesia which are determined based on the utilization of water sources, and the determined qualities are based on the characteristics of the water sources of reservoir and their utilization.
Water sources can be classified into four classes as follows:

Class A, the water which can be used as the source for drinking water directly without prior processing.

Class B, the water which can be used as the raw water for drinking water.

Class $C$, the water that can be used for fishery and livestock.

Class D, the water that can be used for agricultural purposes, and can be utilized for urban business, industry, hydropower generation/plant.

Water quality is a measure of water condition seen from physical, chemical, and biological characteristics. There are some requirements that need to be known about the water quality physically, chemically, and microbiologically. Here is a list of requirements of water quality:

1. Physical requirements:
a. Clean and not muddy.
b. Colorless.
c. Tasteless.
d. Odorless.
e. Temperatures between $10-25^{\circ} \mathrm{C}(\mathrm{cool})$.
f. Leaving no sediment.

2. Chemical requirements:
a. Not containing toxic chemicals.
b. Not containing excessive chemicals.
c. Enough iodine.
d. Water $\mathrm{pH}$ ranging from 6.5 to 9.2 .

3. Microbiological requirements:

Not containing germs, such as dysentery, typhoid, cholera, and bacterial pathogens that can cause diseases.

Water quality is a very complex subject and reflected on the types of measurement and indicators of water used. The measurements will be more accurate if performed directly in the place because the water is in its original condition. For more complex measurements, it requires water samples that should be taken care to protect the real condition, which are then transferred and analyzed elsewhere. Such measurement has two problems, namely the characteristics of the water in the sample may not be the same as the source water due to chemical and biological changes over time and the water that has been separated from its environment will adapt to the new environment, the bottle or packaging used in the sampling.

The materials used for the sampling should therefore have a minimum level of reactivity so as not to affect the quality of the 
water tested. The air space formed in the sample packaging may also have some impact because there is a risk of air dissolving into the water sample. Maintaining the quality of samples can be done by cooling the sample, thereby reducing the rate of chemical reactions and phase changes.

Table 1. List of Water Criteria of Class B (water that can be used as raw water for drinking water)

\begin{tabular}{|c|c|c|c|c|}
\hline No & Parameter & Unit & Maximum content & Note \\
\hline A & Physical & & & \\
\hline 1 & Temperature & ${ }^{\circ} \mathrm{C}$ & Water temperature & Normal $\pm 3^{\circ} \mathrm{C}$ \\
\hline 2 & Total Dissolved Solids (TDS) & $\mathrm{mg} /$ liter & 1,000 & \\
\hline \multirow[t]{2}{*}{ B } & Chemical & & & \\
\hline & Inorganic Chemical & & & \\
\hline 1 & Mercury & $\mathrm{mg} /$ liter & 0.001 & \\
\hline 2 & Free Ammonia & $\mathrm{mg} / \mathrm{liter}$ & 0.5 & \\
\hline 3 & Arsenic & $\mathrm{mg} /$ liter & 0.05 & \\
\hline 4 & Barium & $\mathrm{mg} / \mathrm{liter}$ & 1 & \\
\hline 5 & Iron & $\mathrm{mg} /$ liter & 5 & \\
\hline 6 & Fluoride & $\mathrm{mg} /$ liter & 1.5 & \\
\hline 7 & Cadmium & $\mathrm{mg} / \mathrm{liter}$ & 0.018 & \\
\hline 8 & Cloride & $\mathrm{mg} /$ liter & 600 & \\
\hline 9 & Chromium valence 6 & $\mathrm{mg} / \mathrm{liter}$ & 5 & \\
\hline 10 & Manganese & $\mathrm{mg} /$ liter & 0.5 & \\
\hline 11 & Nitrates, as $\mathrm{N}$ & $\mathrm{mg} /$ liter & 10 & \\
\hline 12 & Nitrite, as $\mathrm{N}$ & $\mathrm{mg} / \mathrm{liter}$ & 1 & \\
\hline 13 & Dissolved Oxygen (DO) & $\mathrm{mg} /$ liter & 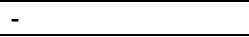 & \\
\hline 14 & $\mathrm{pH}$ & $\mathrm{mg} /$ liter & $5-9$ & Recommended surface water $\geq 6$ \\
\hline 15 & Selenium & $\mathrm{mg} / \mathrm{liter}$ & 0.01 & \\
\hline 16 & Zinc & $\mathrm{mg} /$ liter & 5 & \\
\hline 17 & Cyanide & $\mathrm{mg} / \mathrm{liter}$ & 0.1 & \\
\hline 18 & Sulfate & $\mathrm{mg} /$ liter & 400 & \\
\hline 19 & Sulphide as $\mathrm{H}_{2} \mathrm{~S}$ & $\mathrm{mg} /$ liter & 0.1 & \\
\hline 20 & Copper & $\mathrm{mg} /$ liter & 1 & \\
\hline \multirow[t]{2}{*}{21} & Lead & $\mathrm{mg} /$ liter & 0.1 & \\
\hline & Organic Chemical & & & \\
\hline 1 & Aldrin and dieldrin & $\mathrm{mg} /$ liter & 0.017 & \\
\hline 2 & Chlordane & $\mathrm{mg} /$ liter & 0.003 & \\
\hline 3 & DDT & $\mathrm{mg} /$ liter & 0.042 & \\
\hline
\end{tabular}

\section{MATERIALS AND METHODS}

\section{Literature review}

At this stage, the books, research reports and others related directly and indirectly to the research methods were studied.

\section{Data collection}

Data used in this research were secondary data from taps, and primary data from observations in the field.

\section{Secondary data}

Secondary data were obtained from PDAM Bandarmasih

\section{Primary data}

The measurements of water quality in the field used $\mathrm{pH}$-meter and EC-meter (temperature, TDS and DHL) and the sampling to be tested further in the laboratory used U-50 HORIBA.

\section{Study area}

PDAM Bandarmasih has 4 intake units along with 2 water treatment plants.

Table 2. Data of Water Treatment Plants of PDAM Bandarmasih

\begin{tabular}{lll}
\hline No & Water Treatment Plant (WTP) & Capacity (liter/second) \\
\hline 1 & WTP I A. Yani & 550 \\
\hline 2 & WTP II Pramuka & 1,500 \\
\hline 3 & Production Unit of Mini Treatment Plan (MTP) Sungai Lulut & 50 \\
\hline Total & & 2,100 \\
\hline
\end{tabular}


Table 3. Data of Intake Capacity of PDAM Bandarmasih

\begin{tabular}{lll}
\hline No & Intake PDAM Bandarmasih & Capacity (liter/second) \\
\hline 1 & Intake Sungai Bilu & 600 \\
\hline 2 & Intake Sungai Tabuk & 1,750 \\
\hline 3 & Intake Pematang Panjang & 1,100 \\
\hline 4 & Intake Sungai Lulut & 50 \\
\hline Total & & 3,500 \\
\hline
\end{tabular}

(Source: PDAM Bandarmasih)

\section{RESULTS AND DISCUSSIONS}

Data of water quality were collected by direct testing in the field and also by taking the samples at the site and then testing it at the laboratory of Engineering Faculty, Lambung Mangkurat University, to find out the parameters contained in the water. In this study, there were four intake locations in Banjarmasin, namely Sungai Tabuk, Pematang Panjang, Sungai Lulut and Sungai Bilu. The water sampling was conducted on October 9, 2015 from 09:00 to 3:00 pm at sunny weather. The testing of the water source for raw water was carried out during dry season in order to determine the most minimal water quality that can be used for raw water PDAM Bandarmasih in Banjarmasin. In addition, the water sampling was also done at one of the houses neighborhood having the tap installation as the result of a comparison between the water quality that has not been treated and the water distributed to customers.
The parameters tested directly in the field were only the parameters that were considered important in determining water quality. The devices used were TDS meters to measure temperature, electrolyte content, and the amount of solute, and $\mathrm{pH}$ meter used to measure the acidity of water. The data obtained were compared to the water quality criteria of class $B$ because this study examined the water that can be used as raw water for drinking water.

In addition to directly testing the parameters in the field, the analysis of raw water quality parameters was also conducted at the Laboratory of Lambung Mangkurat University using U-50 HORIBA (multi water quality checker) within the time limit of testing, a day after sampling in the field. Data of water quality were collected by dipping the U-50 HORIBA (multi water quality checker) into the water sample or directly in the object you want to find out about the parameters of the water. The results of Water Quality Data Collection results can be seen in Table 4 to Table 8.

\section{Intake Sungai Tabuk}

The quality and quantity of water at intake Sungai Tabuk, located in the downstream of Martapura river, is strongly influenced by the water conditions and water infiltration in the upstream (Meratus).

Table 4. Data of quality testing of raw water at intake PDAM Sungai Tabuk

\begin{tabular}{lccc}
\hline Data Collected & Field Examination & Laboratory Examination & Unit \\
\hline Temperature & 29.13 & & ${ }^{\circ} \mathrm{C}$ \\
\hline Electrical Conductivity & 0.211 & 0.195 & $\mathrm{mS} / \mathrm{cm}$ \\
\hline Total dissolved solids & 0.096 & 0.127 & $\mathrm{~g} / \mathrm{LDS}$ \\
\hline $\mathrm{pH}$ & 5.0 & 5.47 & $\mathrm{pH}$ \\
\hline Turbidity & - & 17.1 & $\mathrm{NTU}$ \\
\hline Salinity & - & 0.1 & $\mathrm{ppm}$ \\
\hline Dissolved Oxygen & - & 2.7 & $\mathrm{mg} / \mathrm{L} \mathrm{DO}$ \\
\hline
\end{tabular}

\section{Intake Pematang Panjang}

At intake Pematang Panjang, there was a local government policy for the development of tourism area and businesses along the banks of the channel in the form of fish farms and tourism. 
Table 5. Data of quality testing of raw water at intake PDAM Pematang Panjang

\begin{tabular}{lccc}
\hline Data Collected & Field Examination & Laboratory Examination & Unit \\
\hline Temperature & 30.6 & & ${ }^{\circ} \mathrm{C}$ \\
\hline Electrical Conductivity & 0.186 & 0.193 & $\mathrm{mS} / \mathrm{cm}$ \\
\hline Total dissolved solids & 0.093 & 0.25 & $\mathrm{~g} / \mathrm{L} \mathrm{TDS}$ \\
\hline $\mathrm{pH}$ & 6.05 & 5.47 & $\mathrm{pH}$ \\
\hline Turbidity & - & 17.5 & $\mathrm{NTU}$ \\
\hline Salinity & - & 0.1 & $\mathrm{ppm}$ \\
\hline Dissolved Oxygen & - & 2.78 & $\mathrm{mg} / \mathrm{L} \mathrm{DO}$ \\
\hline
\end{tabular}

Intake Sungai Lulut

The effect of salinity at intake Sungai Lulut, Kertak Hanyar, is very high because the intake is the closest to estuary.

Table 6. Data of quality testing of raw water at intake Sungai Lulut

\begin{tabular}{lccc}
\hline Data Collected & Field Examination & Laboratory Examination & Unit \\
\hline Temperature & 29.3 & & ${ }^{\circ} \mathrm{C}$ \\
\hline Electrical Conductivity & $*$ & 6.99 & $\mathrm{mS} / \mathrm{cm}$ \\
\hline Total dissolved solids & $*$ & 4.4 & $\mathrm{~g} / \mathrm{L} \mathrm{TDS}$ \\
\hline $\mathrm{pH}$ & 4.82 & 5.55 & $\mathrm{pH}$ \\
\hline Turbidity & - & 3.8 & $\mathrm{NTU}$ \\
\hline Salinity & - & 3.8 & $\mathrm{ppm}$ \\
\hline Dissolved Oxygen & - & 1.77 & $\mathrm{mg} / \mathrm{L} \mathrm{DO}$ \\
\hline Note: ${ }^{\circ}$ for the experiment of Electrical Conductivity and total dissolved solids exceeding the threshold of device.
\end{tabular}

Intake Sungai Bilu

Intake River Bilu also experienced the same conditions with intake Sungai Lulut, the great effect of salinity caused the water treatment was stopped.

Table 7. Data of quality testing of raw water at intake Sungai Bilu

\begin{tabular}{lccc}
\hline Data Collected & Field Examination & Laboratory Examination & Unit \\
\hline Temperature & 29.0 & & ${ }^{\circ} \mathrm{C}$ \\
\hline Electrical Conductivity & $*$ & 19.9 & $\mathrm{mS} / \mathrm{cm}$ \\
\hline Total dissolved solids & $*$ & 12.5 & $\mathrm{~g} / \mathrm{L} \mathrm{TDS}$ \\
\hline $\mathrm{pH}$ & 5.91 & 5.5 & $\mathrm{pH}$ \\
\hline Turbidity & - & 2.9 & $\mathrm{NTU}$ \\
\hline Salinity & - & 11.8 & $\mathrm{ppm}$ \\
\hline Dissolved Oxygen & - & 1.67 & $\mathrm{mg} / \mathrm{L} \mathrm{DO}$ \\
\hline $\begin{array}{l}\text { Note: }{ }^{*} \text { for the experiment } \\
\text { threshold of } \text { of Electrical }\end{array}$ & Conductivity & and total dissolved solids exceeding the
\end{tabular}

Samples of PDAM's processed water

Table 8. Data of quality testing of PDAM's raw water

\begin{tabular}{lccc}
\hline Data Collected & Field Examination & Laboratory Examination & Unit \\
\hline Temperature & 30.19 & & ${ }^{\circ} \mathrm{C}$ \\
\hline Electrical Conductivity & & 0.336 & $\mathrm{mS} / \mathrm{cm}$ \\
\hline Total dissolved solids & & 0.107 & $\mathrm{~g} / \mathrm{L} \mathrm{TDS}$ \\
\hline $\mathrm{pH}$ & - & 6.57 & $\mathrm{pH}$ \\
\hline Turbidity & - & 2.7 & $\mathrm{NTU}$ \\
\hline Salinity & - & 0.2 & $\mathrm{ppm}$ \\
\hline Dissolved Oxygen & & 1.47 & $\mathrm{mg} / \mathrm{L} \mathrm{DO}$ \\
\hline
\end{tabular}

Note: * for the experiment with TDS in the field at intake Sungai Bilu dan Sungai Lulut, the electrical conductivity and total dissolved solids exceeded the equipment threshold.

The results of water parameters testing in field during the drought on October 9,2015, were severe compared with the experimental results in rainy season ever done at intake River Bilu on 2 April 2015 at 16:03 pm in sunny weather condition, which was representative of the condition at the end of rainy season. 
Table 9. Recapitulation of Laboratory Results

\begin{tabular}{lcccccc}
\hline Data Collected & Sungai Tabuk & $\begin{array}{c}\text { Pematang } \\
\text { panjang }\end{array}$ & Sungai Lulut & Sungai Bilu & $\begin{array}{c}\text { Water from } \\
\text { PDAM }\end{array}$ & Unit \\
\hline Temperature & 30.6 & 30.6 & 29.3 & 29.0 & 30.19 & ${ }^{\circ} \mathrm{C}$ \\
\hline Electrical Conductivity & 0.195 & 0.193 & 6.99 & 19.9 & 0.336 & $\mathrm{mS} / \mathrm{cm}$ \\
\hline Total dissolved solids & 0.127 & 0.25 & 4.4 & 12.5 & 0.107 & $\mathrm{~g} / \mathrm{L} \mathrm{TDS}$ \\
\hline $\mathrm{pH}$ & 5.47 & 5.47 & 5.55 & 5.5 & 6.57 & $\mathrm{pH}$ \\
\hline Turbidity & 17.1 & 17.5 & 3.8 & 2.9 & 2.7 & $\mathrm{NTU}$ \\
\hline Salinity & 0.1 & 0.1 & 3.8 & 11.8 & 0.2 & $\mathrm{ppm}$ \\
\hline Dissolved Oxygen & 2.7 & 2.78 & 1.77 & 1.67 & 1.47 & $\mathrm{mg} / \mathrm{L} \mathrm{DO}$ \\
\hline
\end{tabular}

The results in the table are compared with the Regulation of the Minister of Health of the Republic of Indonesia No. 492/Menkes/PER/IV/2010 about drinking water quality requirements. The parameters tested were as follows:

\section{Temperature}

For water quality criteria of Class B (water that can be used as raw water resource for drinking water), the recommended temperature is $\pm 3^{\circ} \mathrm{C}$ of normal temperature $25^{\circ} \mathrm{C}$. From the test results, it is obtained that the value of water temperature was at a temperature above the normal range due to drought condition and tropical climate, where the air temperature affected the water temperature. That some temperature values were beyond the specified ranges could be caused by several factors, such as the influence of the outside temperature affecting the temperature of the water. However, the values were still within the tolerance range of raw water used for drinking water.

\section{Measurement of Electrical Conductivity}

In this case, the electrical conductivity is generally used in hydroponics, aquaculture and freshwater systems to monitor the amount of nutrients, salts or impurities in water. At intake Sungai Lulut and Sungai Bilu, the high salt content resulted in the very high electrical conductivity. When using insitu test equipment in the field, the device could not read values because the values exceeded the maximum.

\section{Total Dissolved Solids}

For water quality criteria of Class B (water that can be used as raw water for drinking water), the maximum value of total dissolved solids (TDS) that is recommended is $1,000 \mathrm{mg} / \mathrm{liter}$ or $1 \mathrm{~g} / \mathrm{liter}$. The test results indicated that the values of total dissolved solids at intake Sungai Lulut and Sungai Bilu were very high. Therefore, during dry season the production at both intakes was stopped.

pH

The recommended $\mathrm{pH}$ value for water quality criteria of Class B is $5-9$ or $\geq 6$ for surface water. The test results indicated that the $\mathrm{pH}$ values were under requirements, but after being processed they met the recommended values as raw water for drinking water.

\section{Turbidity}

The value of water turbidity for Class $B$ was not included in this criterion. But for the water quality criteria of Class $\mathrm{A}$, it is 5 scales of NTU (water that can be used directly for drinking water without processing). The test results indicated the high turbidity values at two intakes, Sungai Tabuk and Pematang Panjang, but after treatment they showed less than 5 NTU.

\section{Salinity measurement}

The salinity value for Class B is not included in this criterion. But in primary data collection by U-50 HORIBA (multi water quality checker), the salinity value will be automatically obtained. The salinity values recommended for raw water quality criteria were not limited; therefore, the water samples were included in the criteria of water that can be used as raw water for drinking water.

\section{Dissolved Oxygen Measurement}

The recommended values of dissolved oxygen (DO) for Class B are not limited. Therefore, the water samples were included in the criteria of water for being able to be used as raw water for drinking water.

\section{CONCLUSION}

The conclusion that can be drawn from the study on the water quality of raw water 
sources of PDAM Bandarmasih at 4 intakes, Sungai Tabuk, Pematang Panjang, Sungai Lulut and Sungai Bilu, as well as its comparison with the test results of the quality of the water from PDAM distributed to customers in dry season showed that the salinity at two intakes, Sungai Lulut and Sungai Bilu, was so high that the production at both intakes was stopped temporarily during dry season. Therefore, the services for water supply during dry season were only performed at intakes Sungai Tabuk and Pematang Panjang, and the distribution in some areas in Banjarmasin was reduced.

\section{REFERENCES}

Agung Rudi PPA. 2000. Calculation of demand for Non-Irrigation Water and Water Resource Utilization in a Region/ City. A set of papers, short courses on System for Water Resources in Region Autonomy II, Preliminary Basic Calculation of Water Resource Engineering, Book 2, Gadjah Mada University, Yogyakarta.
Anonymous, 1998. Technical Guidelines for Planning Master Plan and A Feasibility Study of Systems for Urban Water Supply, Volume II, Directorate General of Human Settlements, the Department of public works, Jakarta.

Anonymous 1, 2010. The Minister Regulation Number 416/PER/IX/1990.

Anonymous, 2014. Banjarmasin City in Figures 2013. The Central Bureau of Statistics. Banjarmasin.

Effendi, Hefni. 2003. Assessing Water Quality. Canisius, Yogyakarta.

Kamulyan, B., 2008. Water Supplies. MPSA Class Module, Civil Engineering Department, Engineering Faculty of Gadjah Mada University, Yogyakarta.

Noor, M. Robiyan, 2015. A Study on Clean Water Demand in Banjarmasin. Student's Thesis, Civil Engineering Department of Lambung Mangkurat University, Banjarbaru.

Prasetyo, AR., 2000. Short Course on System of Water Resources in Region Autonomy. Book 2, Civil Engineering Faculty of Gadjah Mada University, Yogyakarta. 